\title{
ASPECTS REGARDING THE LEVEL OF EDUCATION OF THE POPULATION AND ITS PARTICIPATION IN EDUCATION AND TRAINING PROGRAMS
}

\author{
Florina BRAN ${ }^{a}$, Petrică Sorin ANGHELUȚ $\breve{A}^{b^{*}}$, Daniel MOISEc ${ }^{c}$, Corneliu GUȚU ${ }^{d}$, \\ Gabriel NASTASE \\ ${ }^{a, b, c, d}$ Bucharest University of Economic Studies, Romania \\ e „Dimitrie Cantemir” Christian University, Romania
}

DOI: $10.24818 / \mathrm{IMC} / 2020 / 02.02$

\begin{abstract}
Progress is the goal of any community, whether it is local, regional or national. Thus, the article presents an analysis of the current situation of the level of education of the population in the Member States of the European Union, aged between 25 and 64 years. Education systems are the basis of economic growth and competitiveness. Their adaptation to new changes contributes to the easier identification of the qualifications needs of the labor market. In this way, participation in education and training programs can lead to the creation of new jobs. The article presents a comparative situation of the participation of the population of the European Union in education and training programs.
\end{abstract}

KEYWORDS: education, labor market, European Union

\section{INTRODUCTION}

The aging of the population leads to the frequent occurrence of problems related to the lack of labor force. At the same time, the identification and employment of a quality job can be achieved if individuals have acquired basic skills. Involvement in the social and economic life of a community can be influenced by it. The aging of the population, as well as its health status, influences the aspects related to employment (Burlacu et al., 2018).

Is considered that the improving lifelong learning lead to the acquisition of those skills needed in the labor market. On the other hand, job satisfaction and motivation can be increased through forms and methods of on-the-job training.

An efficient qualification system leads to the development of human resources. Achieving compliance with labor market requirements increases the competitiveness of the labor force.

A competitive economy requires members of the community to have a high level of training. Given the current technological challenges, people with a high level of training can offer innovative solutions to solve them.

It want young people to benefit from new opportunities in terms of the quality of education and training (EC, 2016). Young people can benefit from the exchanges of experience that take place between the different vocational education and training systems in the European Union. In these cases, it is considered that the transition to the labor market can be achieved with a number of facilities (CEDEFOP, 2018).

\footnotetext{
*Corresponding author. E-mail address:sorin.angheluta@gmail.com
} 
The drastic reduction of the working age population, associated with a low level of education, may mean that, in the future, certain regions of the European Union will be characterized by an aging population with a declining workforce (EU, 2011).

Partnerships between education and training institutions, on the one hand, and the labor market can lead to easier interventions in education and training processes. Raising the retirement age, increasing the minimum contribution period to obtain a decent pension, increase the importance that must be given to lifelong participation in education and training programs.

Improving skills and competencies allows filling for jobs with high levels of training.

The economic progress of the community is influenced by the decisions that the members of that community make. A high level of their education contributes to increasing the relevance of these decisions.

European cooperation in vocational education and training supports the development of education and training systems. Economic prosperity can be achieved through the social, professional, and personal fulfillment of community members. At the same time, prosperity can lead to increased consumption (Rădulescu et al., 2018). Employment does not mean immediate protection against poverty. Long periods of unemployment affect people. Thus, challenges arise in terms of completing competencies through high-level qualifications (Maguire, 2015).

Upgrading skills comes as an effect of changing qualification needs. The acquisition of new skills, knowledge and competencies can be achieved at work (OECD, 2017). In order to acquire the skills required by the labor market, increasing the mobility of people, as well as digitalization, lead to the need for new methods of education and training (EC, 2017).

The level of education of the population can lead to important changes in the economic and social activity of a community. Economic growth and competitiveness are based on strong education systems. The skills needs of the labor market can be more easily identified by adapting education systems to new changes. The creation of new jobs can be achieved by increasing the share of participation in education and training programs. Thus, the relevance of this paper is given by the analyzes performed regarding the situation of the education level of the population aged between 25 and 64, respectively the participation of the population of the European Union in education and training programs.

\section{RESULTS AND DISCUSSIONS}

The negative aspects regarding the discrepancies between the skills of graduates and the skills required by the labor market can be overcome by investment measures in education (EC, 2018). Therefore, it is important to know the level of education of the population. Table 1 presents the comparative situation of the population by educational attainment level, for the member countries of the European Union, for the period 2010-2019 (\%).

From the data presented in the previous table, it is observed that in 2019 , compared to 2010 , the percentage of people aged between 25 and 64 with less than primary, primary and lower secondary education (levels 0-2) decreased both to at European level, as well as at the level of each country. The most significant decreases were: Malta, Portugal, Greece, Ireland. However, in 2019, in ten countries at least two out of ten people had a low level of education (levels 0-2). These are: Portugal (47.8\%), Malta (44.8\%), Spain (38.7\%), Italy (37.8\%), Greece (23.2\%), Belgium (21.3\%), Romania (21.0\%), Luxembourg (20.7\%), Netherlands (20.4\%), France (19.6\%). For four of them, the percentage is very high. Approximately 4 out of 10 people have a low level of education (less than primary, primary and lower secondary education): Portugal, Malta, Spain, Italy.

Regarding the tertiary level of education (levels 5-8), it is observed that in 2019, compared to 2010, the percentage of people aged between 25 and 64 with tertiary education increased both at European level and at the level of each country. The highest increases were in Austria $(+14.7 \%)$, Malta $(+13.7 \%)$, Luxembourg $(+11.5 \%)$, Portugal $(+10.8 \%)$, Lithuania $(+10,7 \%)$, Sweden $(+10.1 \%)$. 
However, in 2019, in six countries at most two out of ten people had a high level of education (levels 5-8). These are: Romania (18.4\%), Italy (19.6\%), Czechia (24.2\%), Croatia (25.3\%), Slovakia (25.8\%), Hungary (26.0\%). There are, however, ten countries where 4 out of 10 people have a high level of education (levels 5-8). These are: Ireland (47.3\%), Luxembourg (47.0\%), Finland (46.0\%), Cyprus (44.7\%), Sweden (44.0\%), Lithuania (43.1\%), Estonia (41.4\%), Belgium (40.7\%), Netherlands (40.4\%), Denmark (40.0\%).

Table 1. Comparative situation of population by educational attainment level, 2010-2019 (\%)

\begin{tabular}{|c|c|c|c|c|}
\hline \multirow[t]{2}{*}{ Countries } & \multicolumn{2}{|c|}{$\begin{array}{l}\text { Less than primary. } \\
\text { primary and lower } \\
\text { secondary education } \\
\text { (levels } 0 \text {-2) }\end{array}$} & \multicolumn{2}{|c|}{$\begin{array}{l}\text { Tertiary education } \\
\text { (levels 5-8) }\end{array}$} \\
\hline & 2010 & 2019 & 2010 & 2019 \\
\hline $\begin{array}{l}\text { European } \\
\text { Union }\end{array}$ & 27.8 & 21.6 & 24.6 & 31.6 \\
\hline Belgium & 29.5 & 21.3 & 35.0 & 40.7 \\
\hline Bulgaria & 20.9 & 17.5 & 23.3 & 28.1 \\
\hline Czechia & 8.1 & 6.2 & 16.8 & 24.2 \\
\hline Denmark & 24.7 & 18.5 & 33.0 & 40.0 \\
\hline Germany & 13.9 & 13.4 & 26.7 & 29.9 \\
\hline Estonia & 10.7 & 9.8 & 35.5 & 41.4 \\
\hline Ireland & 26.9 & 16.3 & 38.7 & 47.3 \\
\hline Greece & 37.3 & 23.2 & 24.0 & 31.9 \\
\hline Spain & 47.1 & 38.7 & 31.0 & 38.6 \\
\hline France & 29.3 & 19.6 & 28.9 & 37.9 \\
\hline Croatia & 22.7 & 14.2 & 18.6 & 25.3 \\
\hline Italy & 44.9 & 37.8 & 14.8 & 19.6 \\
\hline Cyprus & 26.0 & 17.5 & 35.7 & 44.7 \\
\hline Latvia & 11.4 & 8.8 & 26.9 & 35.7 \\
\hline Lithuania & 8.1 & 5.0 & 32.4 & 43.1 \\
\hline Luxembourg & 22.3 & 20.7 & 35.5 & 47.0 \\
\hline Hungary & 18.8 & 15.0 & 20.0 & 26.0 \\
\hline Malta & 67.0 & 44.8 & 14.9 & 28.6 \\
\hline Netherlands & 27.6 & 20.4 & 32.0 & 40.4 \\
\hline Austria & 17.6 & 14.4 & 19.1 & 33.8 \\
\hline Poland & 11.5 & 7.4 & 22.5 & 32.0 \\
\hline Portugal & 68.3 & 47.8 & 15.5 & 26.3 \\
\hline Romania & 26.1 & 21.0 & 13.6 & 18.4 \\
\hline Slovenia & 16.7 & 11.2 & 23.7 & 33.3 \\
\hline Slovakia & 9.0 & 8.6 & 17.3 & 25.8 \\
\hline Finland & 17.0 & 9.9 & 38.1 & 46.0 \\
\hline Sweden & 18.8 & 13.9 & 33.9 & 44.0 \\
\hline
\end{tabular}

Source: made by the authors based on existing data on the EUROSTAT website (2020)

In any economy, people with higher education bring added value. Education systems are the basis of economic growth and competitiveness. Their adaptation to new changes contributes to the easier 
identification of the skills needs of the labor market. In this way, participation in education and training programs can lead to the creation of new jobs. The analysis of the situation regarding the population with tertiary education, for the 25-64 ages group, is performed with the help of table 2 . From the statistical data published by EUROSTAT, it is observed that, for 2019, in almost all countries females with tertiary education have a higher share than males with tertiary education. The only exception is Germany, where the male population with a tertiary education level is $5.1 \%$ more numerous.

Table 2. Comparative situation of population with tertiary education (levels 5-8), 2019 (\%)

\begin{tabular}{|c|c|c|}
\hline Countries & Males & Females \\
\hline $\begin{array}{c}\text { European } \\
\text { Union }\end{array}$ & 29.3 & 33.8 \\
\hline Belgium & 36.5 & 44.8 \\
\hline Bulgaria & 22.2 & 34.1 \\
\hline Czechia & 22.4 & 26.1 \\
\hline Denmark & 34.6 & 45.5 \\
\hline Germany & 32.4 & 27.3 \\
\hline Estonia & 31.0 & 51.8 \\
\hline Ireland & 43.5 & 51.0 \\
\hline Greece & 30.2 & 33.6 \\
\hline Spain & 35.8 & 41.3 \\
\hline France & 35.1 & 40.6 \\
\hline Croatia & 21.6 & 28.9 \\
\hline Italy & 16.8 & 22.4 \\
\hline Cyprus & 39.3 & 49.9 \\
\hline Latvia & 27.1 & 43.7 \\
\hline Lithuania & 35.5 & 50.4 \\
\hline Luxembourg & 46.1 & 48.0 \\
\hline Hungary & 21.6 & 30.3 \\
\hline Malta & 26.2 & 31.2 \\
\hline Netherlands & 40.0 & 40.8 \\
\hline Austria & 34.2 & 33.4 \\
\hline Poland & 26.2 & 37.7 \\
\hline Portugal & 21.5 & 30.6 \\
\hline Romania & 17.2 & 19.7 \\
\hline Slovenia & 26.8 & 40.2 \\
\hline Slovakia & 21.7 & 29.9 \\
\hline Finland & 38.6 & 53.5 \\
\hline Sweden & 36.8 & 51.4 \\
\hline
\end{tabular}

Source: made by the authors based on existing data on the EUROSTAT website (2020)

The largest difference between the shares of females and males is in Estonia, with an increase of $20.8 \%$ for females. In nine other countries, there is at least a $10 \%$ higher share for women: Latvia $(+16.6 \%)$, Finland $(+14.9 \%)$, Lithuania $(+14.9 \%)$, Sweden $(+14.6 \%)$, Slovenia $(+13.4 \%)$, Bulgaria $(+11.9 \%)$, Poland $(+11.5 \%)$, Denmark $(+10.9 \%)$, Cyprus $(+10.6 \%)$. In 2019, the highest weights in which at least half of females have a tertiary level of education are observed for the countries: Finland, Estonia, Sweden, Ireland, Lithuania.

The following figure, for 2019, shows the weights of females with a level of education between 3 and 8 (upper secondary, post-secondary non-tertiary and tertiary education). 
There are very high values and a good level of training of women for many countries. Weights of more than $90 \%$ of the female population with at least level 3 training are recorded in: Lithuania (96.3\%), Latvia (93.5\%), Poland (93.0\%), Estonia (93.0\%), Czechia (92.7\%), Finland (92.5\%), Slovakia $(90.6 \%)$.

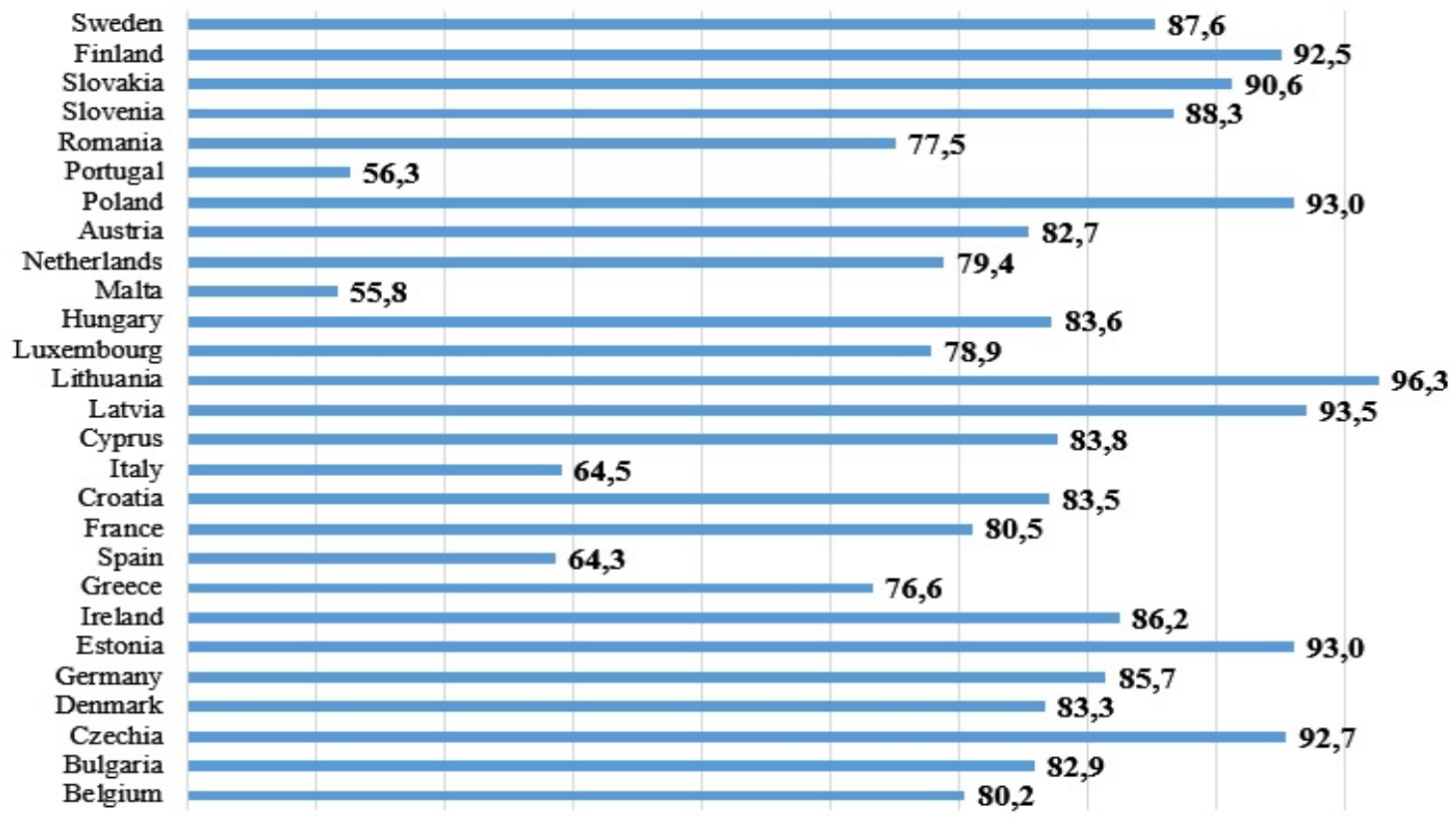

Figure 1. Weights of females with a level of education between 3 and 8 (\%)

Source: made by the authors based on existing data on the EUROSTAT website (2020)

Progress is the goal of any community, whether it is local, regional or national. Given the structure of the population by educational attainment level, it is important to analyze the population's participation in education and training programs.

The following figure shows the evolution of the participation rate in education and training for the population aged between 25 and 64, in the period 2005-2019.

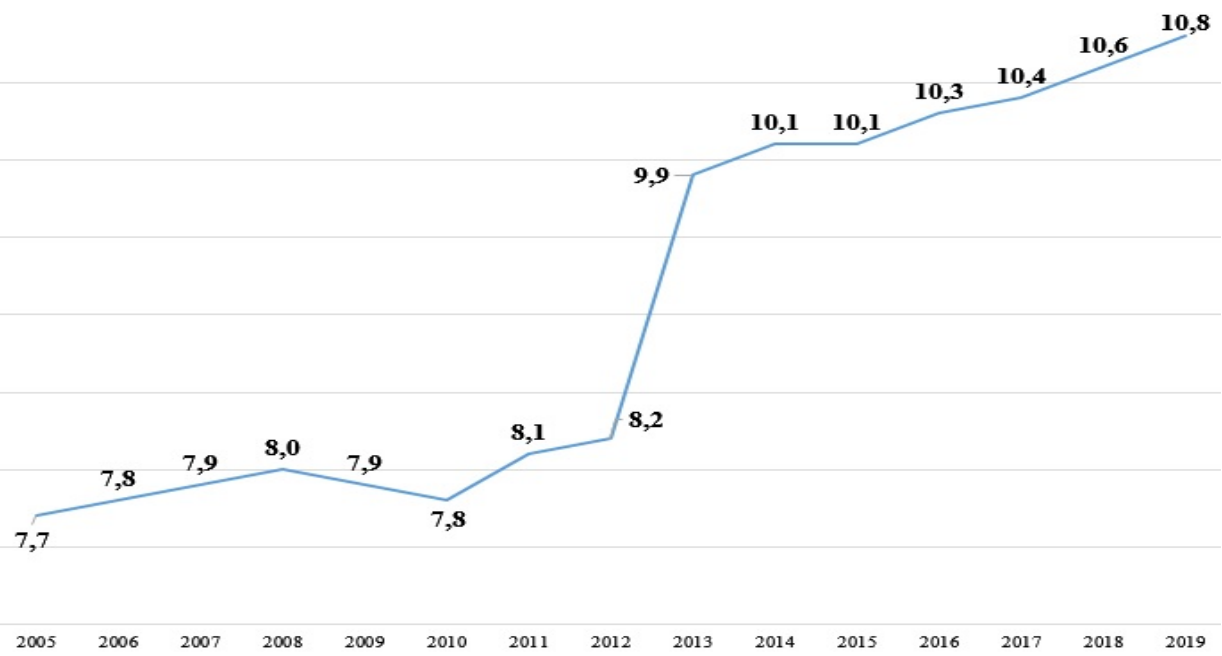

Figure 2. Evolution of participation rate in education and training, 2005-2019 (\%)

Source: made by the authors based on existing data on the EUROSTAT website (2020) 
It is observed that, in the period 2005-2019, in the Member States of the European Union, for the population aged between 25 and 64, the values of the participation rate indicator in education and training increased from $7.7 \%$ (in 2005) at $10.8 \%$ (in 2019), that is by $3.1 \%$.

Table 3. Comparative situation of participation rate in education and training, 2005-2019 (\%)

\begin{tabular}{|c|c|c|c|c|c|c|}
\hline \multirow{2}{*}{ Countries } & \multicolumn{2}{|c|}{ Total } & \multicolumn{2}{c|}{ Males } & \multicolumn{2}{c|}{ Females } \\
\cline { 2 - 7 } & $\mathbf{2 0 0 5}$ & $\mathbf{2 0 1 9}$ & $\mathbf{2 0 0 5}$ & $\mathbf{2 0 1 9}$ & $\mathbf{2 0 0 5}$ & $\mathbf{2 0 1 9}$ \\
\hline European Union & 7.7 & 10.8 & 7.3 & 9.8 & 8.1 & 11.9 \\
\hline Belgium & 8.3 & 8.2 & 8.2 & 7.7 & 8.5 & 8.6 \\
\hline Bulgaria & 1.3 & 2.0 & 1.3 & 1.8 & 1.2 & 2.1 \\
\hline Czechia & 5.6 & 8.1 & 5.2 & 8.1 & 5.9 & 8.1 \\
\hline Denmark & 27.4 & 25.3 & 23.6 & 20.7 & 31.2 & 30.0 \\
\hline Germany & 7.7 & 8.2 & 8.0 & 8.3 & 7.4 & 8.1 \\
\hline Estonia & 6.0 & 20.2 & 4.5 & 17.0 & 7.3 & 23.3 \\
\hline Ireland & 7.4 & 12.6 & 6.2 & 10.7 & 8.6 & 14.5 \\
\hline Greece & 1.9 & 3.9 & 2.0 & 3.7 & 1.8 & 4.2 \\
\hline Spain & 10.8 & 10.6 & 9.8 & 9.5 & 11.7 & 11.7 \\
\hline France & 5.9 & 19.5 & 5.6 & 16.7 & 6.2 & 22.2 \\
\hline Croatia & 2.1 & 3.5 & 2.0 & 3.2 & 2.1 & 3.7 \\
\hline Italy & 5.8 & 8.1 & 5.4 & 7.7 & 6.2 & 8.6 \\
\hline Cyprus & 5.9 & 5.9 & 5.4 & 5.6 & 6.3 & 6.2 \\
\hline Latvia & 7.8 & 7.4 & 4.8 & 5.4 & 10.6 & 9.3 \\
\hline Lithuania & 6.1 & 7.0 & 4.3 & 5.5 & 7.8 & 8.5 \\
\hline Luxembourg & 8.5 & 19.1 & 8.5 & 19.7 & 8.5 & 18.5 \\
\hline Hungary & 3.9 & 5.8 & 3.2 & 5.6 & 4.6 & 6.0 \\
\hline Malta & 5.2 & 12.0 & 5.8 & 10.7 & 4.7 & 13.4 \\
\hline Netherlands & 15.4 & 19.5 & 15.1 & 18.5 & 15.8 & 20.4 \\
\hline Austria & 12.9 & 14.7 & 12.3 & 13.1 & 13.6 & 16.3 \\
\hline Poland & 4.9 & 4.8 & 4.3 & 4.2 & 5.4 & 5.4 \\
\hline Portugal & 4.1 & 10.5 & 4.0 & 10.3 & 4.2 & 10.7 \\
\hline Romania & 1.6 & 1.3 & 1.5 & 1.4 & 1.6 & 1.2 \\
\hline Slovenia & 15.3 & 11.2 & 13.6 & 9.7 & 17.2 & 12.8 \\
\hline Slovakia & 4.6 & 3.6 & 4.3 & 3.6 & 5.0 & 3.6 \\
\hline Finland & 22.5 & 29.0 & 19.0 & 24.8 & 26.1 & 33.3 \\
\hline Sweden & 17.4 & 34.3 & 13.0 & 26.1 & 21.9 & 42.9 \\
\hline
\end{tabular}

Source: made by the authors based on existing data on the EUROSTAT website (2020)

From the data presented in the previous table, for the entire population aged between 25 and 64 , it is observed that, compared to 2005, in 2019 the highest increases were registered in: Sweden $(+16.9 \%)$, Estonia $(+14.2 \%)$, France $(+13.6 \%)$, Luxembourg $(+10.6 \%)$, Malta $(+6.8 \%)$, Finland $(+6.5 \%)$, Portugal $(+6.4 \%)$, Ireland $(+5.2 \%)$. Also, for the same period analyzed, in the following countries the values decreased: Slovenia (-4.1\%), Denmark (-2.1\%), Slovakia (-1.0\%), Latvia ($0.4 \%)$, Romania $(-0.3 \%)$, Spain $(-0.2 \%)$. However, the situation is different for the values recorded in 2019. Thus, the following countries had the highest values for participation rate in education and training: Sweden (34.3\%), Finland (29.0\%), Denmark (25.3\%), Estonia (20.2\%), France (19.5\%), the Netherlands (19.5\%), Luxembourg (19.1\%). The lowest values were registered in: Romania $(1.3 \%)$, Bulgaria $(2.0 \%)$, Croatia (3.5\%), Slovakia (3.6\%), Greece $(3.9 \%)$, Poland $(4.8 \%)$. The values are similar for both males and females.

Higher education is important in the context of the emergence of new technologies. Thus, another indicator is given by students enrolled in tertiary education. The comparative situation of students enrolled in tertiary education, for 2013, respectively 2018, is presented in the following table. 


\section{Table 4. The comparative situation of students enrolled in tertiary education,} 2013-2018 (number)

\begin{tabular}{|c|c|c|}
\hline Countries & $\mathbf{2 0 1 3}$ & $\mathbf{2 0 1 8}$ \\
\hline $\begin{array}{c}\text { European } \\
\text { Union }\end{array}$ & 17231328 & 17502046 \\
\hline Belgium & 488488 & 515530 \\
\hline Bulgaria & 283959 & 236335 \\
\hline Czechia & 427441 & 329036 \\
\hline Denmark & 291147 & 310903 \\
\hline Germany & 2780013 & 3127927 \\
\hline Estonia & 64806 & 45773 \\
\hline Ireland & 199428 & 231201 \\
\hline Greece & 658474 & 766874 \\
\hline Spain & 1969413 & 2051826 \\
\hline France & 2338135 & 2618729 \\
\hline Croatia & 164623 & 164826 \\
\hline Italy & 1872693 & 1895990 \\
\hline Cyprus & 31965 & 47169 \\
\hline Latvia & 94474 & 81602 \\
\hline Lithuania & 159695 & 118287 \\
\hline Luxembourg & 6617 & 7043 \\
\hline Hungary & 359040 & 283350 \\
\hline Malta & 12574 & 15220 \\
\hline Netherlands & 674752 & 889506 \\
\hline Austria & 422778 & 430195 \\
\hline Poland & 1902718 & 1492861 \\
\hline Portugal & 360818 & 356390 \\
\hline Romania & 618157 & 538871 \\
\hline Slovenia & 97706 & 76534 \\
\hline Slovakia & 209543 & 144447 \\
\hline Finland & 309009 & 294516 \\
\hline Sweden & 436603 & 431065 \\
\hline
\end{tabular}

Source: made by the authors based on existing data on the EUROSTAT website (2020)

It is observed that, at European level, in 2018 compared to 2013, the number of students enrolled in tertiary education increased by only $1.65 \%$. The particular situation for the countries of the European Union is, however, very different. Thus, in more than half of them the number of students decreased. The countries with the largest decreases are: Slovakia (-26.99\%), Estonia (-23.71\%), Czech Republic (-21.40\%), Lithuania (-20.29\%), Slovenia (-17.50\%), Bulgaria (-16.58\%), Poland ($15.31 \%)$, Hungary $(-13.99 \%)$. At the same time, there were significant increases: Cyprus $(+40.08 \%)$, Netherlands $(+26.68 \%)$, Malta $(+20.70 \%)$, Ireland $(+13.38 \%)$, France $(+9.62 \%)$, Germany (+7.41\%), Greece (+5.66\%). In 2018, the countries with the most students were: Germany, France, Spain, Italy, Poland, Netherlands, Greece, Romania.

\section{CONCLUSIONS}

Much more attention should be paid to the education and training process. The degree to which the population holds a job is also influenced by its level of education. 
Following the analysis, it was found that, both at European level and at the level of each country, the percentage of people aged between 25 and 64 with less than primary, primary and lower secondary education (levels 0-2) decreased. Also, the percentage of people aged between 25 and 64 with tertiary education has increased.

Corresponding to 2019, it is observed that in almost all countries females with tertiary education have a higher share than males with tertiary education.

Regarding participation rate in education and training, in 2019, in the following countries approximately one in five people participated in education and training programs: Sweden, Finland, Denmark, Estonia, France, Netherlands, Luxembourg.

At the level of the European Union, in 2018 compared to 2013, the number of students enrolled in tertiary education increased very little $(+1.65 \%)$. The particular situation is, however, very different, so in more than half of the countries the number of students has decreased.

All these results represent both a current and a future image of the labor market. Thus, potential investors can make the decision to start a productive activity in one region or another depending on the level of education of the population in that region.

Participation in education and training programs influences the broadening of individual perspectives, as well as personal development.

\section{REFERENCES}

Burlacu, S., Rădulescu, C.V., \& Bălu, O.F. (2018). Forms of Electronic Training. Principles of Educational Games. Proceedings of the International Conference on Economics and Social Sciences, Bucharest University of Economic Studies, Romania, Vol. 1(1), 36-41.

European Centre for the Development of Vocational Training. (CEDEFOP) (2018). European cooperation in VET: one process, many stops. Developments in vocational education and training policy 2015-17. Luxembourg: Publications Office.

European Commission. (2016). Next steps for a sustainable European future European action for sustainability. Retrieved July 07, 2020, from https://eur-lex.europa.eu/legalcontent/EN/TXT/?uri=COM\%3A2016\%3A739\%3AFIN.

European Commission. (2017). Reflection paper on harnessing globalization. Retrieved July 09, 2020, from https://ec.europa.eu/commission/publications/reflection-paper-harnessingglobalisation_en

European Commission. (2018). Building a stronger Europe: the role of youth, education and culture policies. Retrieved July 08, 2020, from https://eur-lex.europa.eu/legalcontent/EN/TXT/PDF/?uri=CELEX:52018DC0268\&from=EN.

European Union. (2011). 2020 - The rol of Regional Policy in the future of Europe. Panorama Inforegio, (39). Retrieved July 09, 2020, from https://ec.europa.eu/regional_policy/en/information/publications/panoramamagazine/2011/panorama-39-2020-the-role-of-regional-policy-in-the-future-of-europe

EUROSTAT. (2020). http://ec.europa.eu/eurostat, accession date June 2020

Maguire, S. (2015). Young people not in education, employment or training (NEET): Recent policy initiatives in England and their effects, Research in Comparative and International Education, 10 (4), 525-536. Retrieved July 10, 2020, from https://journals.sagepub.com/doi/10.1177/1745499915612186.

Organization for Economic Cooperation and Development. (2017). Educational Opportunity for All: Overcoming Inequality throughout the Life Course, OECD Publishing, Paris.

Rădulescu, C.V., Bodislav, D.A., \& Burlacu, S. (2018). Demographic explosion and IT governance in public institutions. Managerial Challenges of the Contemporary Society, 11(1), 18. 